\title{
Prevalence of asthma and allergic disorders among children in united Germany: a descriptive comparison
}

\author{
Erika von Mutius, Christian Fritzsch, Stephan K Weiland, Gabriele Röll, Helgo Magnussen
}

\begin{abstract}
Objectives-To compare the prevalence of asthma and allergic disorders among children in Munich, western Germany, and Leipzig, eastern Germany, where environmental exposure, particularly air concentrations of sulphur dioxide and particulate matter, and living conditions have differed over the past 45 years.
\end{abstract}

Design-Prevalence surveys among schoolchildren aged 9-11 years in Leipzig and Munich. Self completion of written questionnaire by the children's parents and lung function measurements.

Subjects-1051 children in Leipzig and 5030 in Munich.

Setting-Primary schools.

Main outcome measures-Reported lifetime prevalence of asthma and allergic disorders, and bronchial hyperresponsiveness assessed by cold air inhalation challenge.

Results-The lifetime prevalence of asthma diagnosed by a doctor was $7 \cdot 3 \%(72)$ in Leipzig and $9 \cdot 3 \%$ (435) in Munich; prevalences of wheezing were $20 \%$ (191) and $17 \%$ (786) respectively. The prevalence of diagnosed bronchitis was higher in Leipzig than Munich (30.9\% (303) $v$ 15.9\% (739); p <0.01). A significant drop in forced expiratory volume $(>9 \%)$ after cold air challenge was measured in $6.4 \%$ (57) of children in Leipzig and in $7 \cdot 7 \%(345)$ of those in Munich. Hay fever (2.4\% (24) $v 8.6 \%(410) ; p<0.01)$ and typical symptoms of rhinitis $(16.6 \%$ (171) $v$ $19.7 \%(961) ; p<0.05)$ were reported less often in Leipzig than in Munich.

Conclusions-No significant differences were seen in the lifetime prevalence of asthma, wheezing, and bronchial hyperresponsiveness between children in Leipzig and Munich. The lifetime prevalence of bronchitis was higher in Leipzig than in Munich. The lower prevalence rates of allergic disorders in Leipzig could point toward aetiological factors that are associated with Western lifestyle and living conditions.

\section{Medicine and}

Epidemiology, Ruhr

University, 4630 Bochum,

Germany

Stephan K Weiland,

epidemiologist

Research Centre for Environment and Human Health, GSF Medis Institute, 8000 Munich, Germany

Gabriele Röll, statistician

Zentrum für Pneumologie und Thoraxchirurgie, Krankenhaus

Grosshansdorf Hamburg, Germany

Helgo Magnussen,

respiratory physician

Correspondence to:

Dr von Mutius.

BMF 1992;305:1395-9
Morbidity related to asthma has been reported to be increasing in Western countries..$^{1-5}$ Rates of death and Zealand, Switzerland,' and Wales ${ }^{2}$ have found ently higher prevalences of asthma and wheezing earlier. Although changes in medical practice, diagnostic labelling, and public awareness could have influenced these trends, Burney et al suggested that the is real. ${ }^{3}$ Similar changes have been for the prevalence of hay fever ${ }^{121011}$ and eczema in hildren. ${ }^{1212}$

The causes of the apparent increase in the prevalences of asthma and allergic disorders remain unclear. Domestic factors such as exposure to house dust mites, ${ }^{13}$ cigarette smoke ${ }^{14}$ or family size ${ }^{15}$ have been incriminated, as have environmental factors such as air pollution due to sulphur dioxide, particulate matter, nitrogen dioxide, ozone, or vehicle exhausts. ${ }^{16-21}$
The reunification of Germany provided a unique opportunity to study two genetically similar populations who over the past 45 years have been exposed to different living conditions and levels of environmental pollution. In particular, the type of air pollution differs greatly between western and eastern Germany. The objective of this study was to compare the prevalence of asthma and allergic disorders among children in Munich, western Germany, and Leipzig, eastern Germany, where air concentrations of sulphur dioxide are particularly high. A prevalence survey of 9-11 yea old children was carried out in both cities by the same methods.

Subjects and methods

STUDY AREAS AND POPULATIONS

Munich is a city with moderate industry and heavy traffic, has a population of about 1.3 million, and is located in southern Bavaria. All fourth grade pupils $(n=7445)$ at all primary schools in Munich were included in the study. Leipzig, a city with heavy ai pollution caused by private coal burning and industria emissions, has about 535000 inhabitants and is located in north west Saxony. All pupils $(n=1429)$ attending classes of the fourth grade at a random sample of 28 schools were included in the study.

The study was approved by the ethics committee of the Bavarian Medical Society. We studied children in Munich from September 1989 until July 1990 and those in Leipzig from January 1991 until June 1991.

\section{QUESTIONNAIRE}

A self administered questionnaire was distributed through the schools to the parents of the children. The questionnaire was developed according to international recommendations ${ }^{22}$ and included questions concerning sociodemographic characteristics, doctors diagnoses, typical symptoms of respiratory and allergic disorders, triggers and seasonal patterns of these health problems, therapeutic management, and possible aetiological factors.

Parents were asked: has a doctor ever diagnosed one of the following diseases in your child? (a) asthma, (b) wheezy bronchitis, $(c)$ bronchitis, $(d)$ none of these. In addition, parents were asked whether the condition had occurred only once or more than once. Children whose parents reported either asthma or recurrent wheezy bronchitis were classified as having asthma Children with reported recurrent bronchitis only wer defined as having bronchitis. Additional questions included: has your child ever had wheezing or whistling in the chest? has your child ever had attacks of shortness of breath? does your child cough frequently during the night? does your child cough frequently after exercise or during foggy or cold weather? has doctor ever diagnosed hay fever in your child? has your child had a runny, stuffy, or itching nose without a cold in the past 12 months? what are the causes of these nose problems? do these symptoms occur during specific months? has a doctor ever diagnosed eczema in your child? has your child ever had itchy rashes in the creases of the knees, elbows, or wrists? 
I.LNG FLNCTION MEASLREMENTS

The Pneumoscope II (Jäger, Würzburg, Germany) was used to test pulmonary function. Forced expiratory manoeuvres were performed and flow volume curves recorded until three reproducible loops were obtained. The highest readings for forced expiratory volume in one second and forced vital capacity during any manoeuvre were used. Cold air hyperventilation was induced with the RHES (respiratory heat exchange system) cold air hyperventilation provocation device (Jäger, Würzburg). Each child did four minutes of isocapnic ( $5 \%$ carbon dioxide) hyperventilation (that is, $22 \times$ forced expiratory volume/minute) of dry and cold air $\left(-15^{\circ} \mathrm{C}\right.$, at the mouthpiece). Ventilatory effort was guided by a target balloon. The balloon was filled with air at the predetermined rate and had to be kept filling through the respiratory effort of the children. Lung function tests were repeated four minutes after completion of cold air provocation. Only children whose parents had given informed consent participated.

Lung function parameters are expressed as percentages of the predicted value. The 95th centile of the reference population (932 German children without any allergic or respiratory disorders in Munich) was defined as the cut off point. ${ }^{23}$ Percentage changes of forced expiratory volume in one second $\left(\mathrm{FEV}_{1}\right)$ after cold air inhalation are calculated as $\left(\mathrm{FEV}_{1}\right.$ after inhalation $-\mathrm{FEV}_{1}$ before inhalation) $\times 100 / \mathrm{FEV}$ before inhalation.

\section{AIR POLLUTION}

Information about the air pollution was derived from reports of the responsible local agencies-that is, Bayerisches Landesamt für Umweltschutz in Munich and Landesuntersuchungsanstalt für das Gesundheitsund Veterinärwesen Sachsen in Leipzig. The data for 1989 are presented because they reflect best the long term exposure of children in both areas before the drastic changes occurred in Leipzig following German reunification. The measurement technique for particulate matter ( $\beta$ absorption) was comparable in both areas, and reflects the concentration of particles of less than $30-40 \mu \mathrm{m}$. Sulphur dioxide in Leipzig was

FIG 1 - Average monthly concentration of sulphur dioxide and particulate matter in Munich and Leipzig in 1989.

Measurements of particulate matter in Leipzig were not available for fanuary, August, September, and October

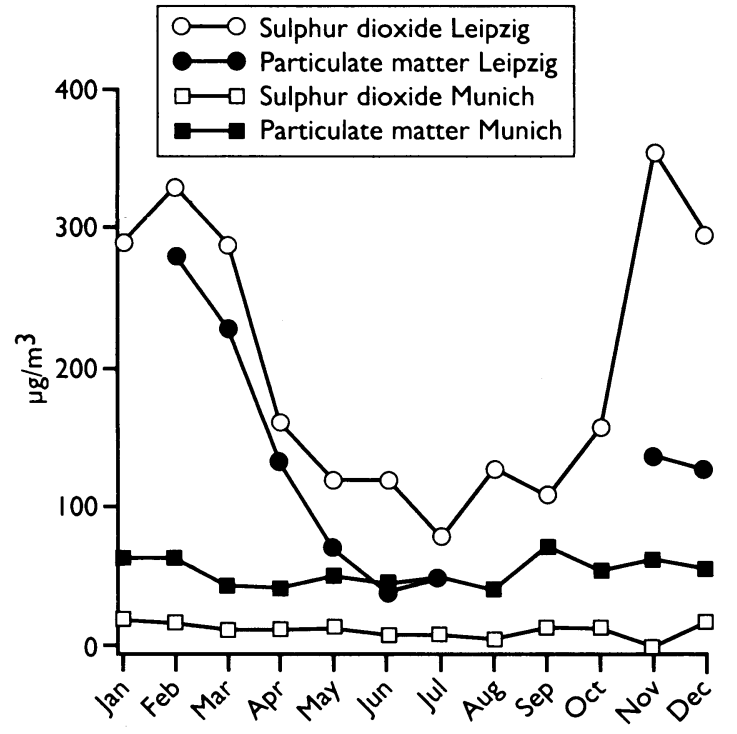

TABLE I-Mean (95\% confidence interval) age, height, and body weight of the study of children in Leipzig and Munich

\begin{tabular}{|c|c|c|c|c|}
\hline & \multicolumn{2}{|c|}{ Leipzig $(n=1051)$} & \multicolumn{2}{|c|}{ Munich $(n=5030)$} \\
\hline & Boys $(n=491)$ & Girls $(n=560)$ & Boys $(n=2445)$ & Girls $(n=2585)$ \\
\hline Age (years & $9.92(9.88$ to 9.96$)$ & $9.91(9.87$ to 9.95$)$ & $9.82(9.80$ to 9.84$)$ & $9.75(9.73$ to $9 \cdot 77)$ \\
\hline Height $(\mathrm{cm})$ & $143.2(142.6$ to 143.8$)$ & $143.8(143.3$ to 144.4$)$ & $143.5(143.2$ to 143.7$)$ & $142.9(142.6$ to 143.2$)$ \\
\hline Weight (kg) & $34.9(34.3$ to 35.5$)$ & $35.3(34.7$ to 35.8$)$ & $34.8(34.5$ to 35.0$)$ & $34 \cdot 4(34 \cdot 1$ to $34 \cdot 6)$ \\
\hline
\end{tabular}

measured by a coulometric method. In 1991, however, this method gave results very similar to data obtained by ultraviolet fluorescence, which was recently installed in Leipzig and was also used in Munich. The reported monthly average concentrations of sulphur dioxide and particulate matter in 1989 differed greatly between Leipzig and Munich (fig 1).

No comparable measurements of nitrogen dioxide were available before 1991 . The annual average concentrations of nitrogen dioxide in 1991, measured by chemiluminescence, were lower in Leipzig $\left(39 \mu \mathrm{g} / \mathrm{m}^{3}\right)$ than in Munich $\left(58 \mu \mathrm{g} / \mathrm{m}^{3}\right)$. Measurements by the Salzmann technique suggest that nitrogen dioxide concentrations in Leipzig have been increasing since 1989. Information about ozone levels is not sufficient to make valid comparisons between the two cities. Measurements recorded in 1991 show annual average concentrations of $39.1 \mu \mathrm{g} / \mathrm{m}^{3}$ in Leipzig and of $31.0 \mu \mathrm{g} / \mathrm{m}^{3}$ in Munich with maximal half hourly concentrations of $236 \mu \mathrm{g} / \mathrm{m}^{3}$ in Leipzig and of $186 \mu \mathrm{g} / \mathrm{m}^{3}$ in Munich during the summer. However, no ozone measurements were available for Leipzig before 1991 and the measurement stations in both cities probably underestimate the ozone concentrations for most parts of the city because they are located along busy roads.

\section{STATISTICAL METHODS}

Based on the prevalence in Munich it was calculated that 1400 children would be needed in Leipzig to detect a difference of $2 \cdot 5 \%$ in the prevalence of asthma with an $\alpha$ error of $5 \%$ and a power of $80 \%$. Prevalences were calculated with $95 \%$ confidence intervals. ${ }^{24}$ Two tailed exact Fisher tests were used to compare prevalence in the two study populations. Prevalence odds ratios were computed as measures of the association between the region and the prevalence of diseases. Al calculations were performed with SAS 6.06 software. ${ }^{2}$

\section{Results}

Parents returned the questionnaire for $1084(75 \cdot 8 \%)$ children in Leipzig and $6490(87.0 \%)$ in Munich. The proportion of children without German nationality was $3.0 \%$ (33) in Leipzig and $22.5 \%$ (1460) in Munich. To keep the two study populations as similar as possible with regard to ethnic background the analysis was restricted to children with German nationality. The remaining children in Leipzig and Munich were similar with regard to sex and age distribution, height, and body weight (table I)

The lifetime prevalence of asthma diagnosed by a doctor was slightly lower in Leipzig than in Munich; the lifetime prevalence of wheeze was slightly higher in Leipzig than in Munich (table II). The reported prevalence of nocturnal cough and shortness of breath was similar in both cities, while coughing after exercise or during foggy or cold weather was reported more often in Leipzig than in Munich (18.6\% (182) v $11.7 \%$ $(560) ; \mathrm{p}<0.05)$. A significant excess of recurrent bronchitis diagnosed by a doctor was found in Leipzig compared with Munich (30.9\% (303) v 15.9\% (739); $\mathrm{p}<0.01)$.

Parents of children in whom a doctor had diagnosed asthma in Leipzig and Munich reported wheezing, shortness of breath, nocturnal cough, and cough after exercise with similar frequency (table III). Parents of children with a doctor's diagnosis of bronchitis without asthma reported cough following exercise or during cold or foggy weather more often in Leipzig than in Munich $(27 \cdot 9 \%(78) v 19 \cdot 0 \%(133) ; \mathrm{p}<0 \cdot 01)$. Nosignificant differences between Leipzig and Munich were found for the reported frequency of wheezing, attacks of shortness of breath, and nocturnal cough among children with bronchitis. 
Table IV shows the reported triggers of asthma attacks for both study populations. Colds and foggy weather were most often incriminated in Leipzig while grass pollen and dust and emotional problems were reported most often as triggers by parents in Munich.

The prevalence of hay fever diagnosed by a doctor was significantly lower in Leipzig than in Munich $(2.4 \%(24) v 8.6 \%(410) ; \mathrm{p}<0.01)$ (table II). Typical symptoms of rhinitis-runny, stuffy, or itching noseduring the previous 12 months were also reported less often in Leipzig than in Munich (16.6\% (171) v 19.7\% $(961) ; p<0.05)$. Allergic triggers of rhinitis symptoms such as grass, pets, or dust were reported also less often

TABLE II-Lifetime prevalence (\%) of respiratory and allergic disorders among 9-11 year old children in Leipzig and Munich

\begin{tabular}{|c|c|c|c|c|c|}
\hline & \multicolumn{2}{|c|}{ Leipzig $(n=1051)$} & \multicolumn{2}{|c|}{ Munich $(n=5030)$} & \multirow[b]{2}{*}{$\begin{array}{c}\text { Odds ratio } \\
\text { (95\% confidence } \\
\text { interval) }\end{array}$} \\
\hline & $\begin{array}{l}\text { No of } \\
\text { children }\end{array}$ & $\begin{array}{c}\text { Prevalence } \\
\text { (95\% confidence } \\
\text { interval) }\end{array}$ & $\begin{array}{l}\text { No of } \\
\text { children }\end{array}$ & $\begin{array}{c}\text { Prevalence } \\
\text { (95\% confidence } \\
\text { interval) }\end{array}$ & \\
\hline \multicolumn{6}{|l|}{ Doctor diagnosed: } \\
\hline Asthma & 72 & $7.3(5.7$ to 9.0$)$ & 435 & $9.3(8.5$ to 10.2$)$ & $0.77(0.59$ to 1.00$)$ \\
\hline Bronchitis & 303 & $30.9(26.0$ to 33.8$)$ & 739 & $15.9(14.8$ to 16.9$)$ & $2.37(2.03 \text { to } 2.77)^{\star \star}$ \\
\hline Hay fever & 24 & $2.4(1.4$ to $3 \cdot 3)$ & 410 & $8 \cdot 6(7.8$ to $9 \cdot 4)$ & $0.26(0.17 \text { to } 0.39)^{\star \star *}$ \\
\hline Atopic dermatitis & 129 & $13.0(10.9$ to 15.1$)$ & 667 & $13.9(12.9$ to 14.9$)$ & $0.93(0.76$ to 1.13$)$ \\
\hline \multicolumn{6}{|l|}{ Reported symptoms: } \\
\hline Wheeze & 191 & $20.0(17.4$ to 22.5$)$ & 786 & $17.0(15.9$ to $18 \cdot 1)$ & $1.22(1.02$ to 1.45$)$ \\
\hline $\begin{array}{l}\text { Attacks of shortness of } \\
\text { breath }\end{array}$ & 73 & $7.3(5.7$ to 8.9$)$ & 416 & $8.7(7.9$ to 9.5$)$ & $0.83(0.64$ to 1.08$)$ \\
\hline Nocturnal cough & 34 & $3.4(2 \cdot 2$ to 4.5$)$ & 166 & $3.4(2.9$ to 3.9$)$ & $0.98(0.67$ to 1.43$)$ \\
\hline $\begin{array}{l}\text { Cough after exercise or } \\
\text { during foggy or cold } \\
\text { weather }\end{array}$ & 182 & $18.6(16.1$ to 21.0$)$ & 560 & $11.7(10.8$ to 12.6$)$ & $1.72(1.43 \text { to } 2.04)^{\star \star}$ \\
\hline Runny, stuffy, or itching & & $100(10.10210)$ & 061 & $11.7(1000120)$ & $0.81<0.6$ \\
\hline Itchy skin, rashes & $\begin{array}{l}171 \\
184\end{array}$ & $\begin{array}{l}16.6(14.4 \text { to } 18.9) \\
18.1(15.7 \text { to } 20.4)\end{array}$ & $\begin{array}{l}901 \\
862\end{array}$ & $17.7(16.7$ to 18.8$)$ & $1.02(0.86$ to 1.22$)$ \\
\hline
\end{tabular}

${ }^{\star} \mathrm{p}<0.05,{ }^{\star \star} \mathrm{p}<0.01$ calculated with Fisher's two tailed exact test.

TABLE III-Prevalence (\%) of respiratory symptoms in children with diagnosed asthma and diagnosed bronchitis in Leipzig and Munich

\begin{tabular}{|c|c|c|c|c|c|}
\hline & \multicolumn{2}{|r|}{ Leipzig } & \multicolumn{2}{|r|}{ Munich } & \multirow[b]{2}{*}{$\begin{array}{l}\text { Odds ratio } \\
\text { (95\% confidence } \\
\text { interval) }\end{array}$} \\
\hline & $\begin{array}{l}\text { No of } \\
\text { children }\end{array}$ & $\begin{array}{c}\text { Prevalence } \\
\text { (95\% confidence } \\
\text { interval })\end{array}$ & $\begin{array}{l}\text { No of } \\
\text { children }\end{array}$ & $\begin{array}{c}\text { Prevalence } \\
\text { (95\% confidence } \\
\text { interval) }\end{array}$ & \\
\hline Children with asthma: & 72 & & 435 & & \\
\hline Wheeze & 51 & $76 \cdot 1(65.9$ to 86.3$)$ & 294 & $73 \cdot 1(68 \cdot 8$ to $77 \cdot 5)$ & $1.18(0.64$ to $2 \cdot 13)$ \\
\hline $\begin{array}{l}\text { Attacks of shortness of } \\
\text { breath- } \\
\text { Nocturnal cough }\end{array}$ & $\begin{array}{l}34 \\
16\end{array}$ & $\begin{array}{l}49.3(37.5 \text { to } 61.1) \\
22.5(12.8 \text { to } 32.3)\end{array}$ & $\begin{array}{r}191 \\
76\end{array}$ & $\begin{array}{l}46.7(41.9 \text { to } 51.5) \\
18.4(14.6 \text { to } 22.1)\end{array}$ & $\begin{array}{l}1.11(0.67 \text { to } 1.85) \\
1.30(0.70 \text { to } 2.38)\end{array}$ \\
\hline $\begin{array}{l}\text { Cough after exercise or } \\
\text { during foggy or cold }\end{array}$ & & & & & \\
\hline $\begin{array}{l}\text { weather } \\
\text { Children with bronchitis: }\end{array}$ & $\begin{array}{r}36 \\
303\end{array}$ & $55 \cdot 4(43 \cdot 3$ to $67 \cdot 5)$ & $\begin{array}{l}187 \\
739\end{array}$ & $45.7(40.9$ to 50.5$)$ & $1.47(0.87$ to 2.50$)$ \\
\hline $\begin{array}{l}\text { Wheeze } \\
\text { Attacks of shortness of }\end{array}$ & 84 & $30.7(25 \cdot 2$ to $36 \cdot 1)$ & 200 & $29.9(26.5$ to 33.4$)$ & $1.04(0.76$ to 1.40$)$ \\
\hline breath & 23 & $8 \cdot 1(4.9$ to 11.3$)$ & 79 & $11 \cdot 4(9 \cdot 1$ to $13 \cdot 8)$ & $0.67(0.42$ to 1.12$)$ \\
\hline $\begin{array}{l}\text { Nocturnal cough } \\
\text { Cough after exercise or } \\
\text { during foggy or cold }\end{array}$ & 14 & $4 \cdot 8(2 \cdot 3$ to $7 \cdot 2)$ & 32 & $4.4(2.9$ to 5.9$)$ & $1.07(0.57$ to 2.04$)$ \\
\hline weather & 78 & $27.9(22.6$ to 33.1$)$ & 133 & $19.0(16.1$ to 21.9$)$ & $1.64(1.19 \text { to } 2.27)^{\star \star}$ \\
\hline
\end{tabular}

${ }^{\star} \mathrm{p}<0.05,{ }^{\star \star} \mathrm{p}<0.01$ by Fisher's two tailed exact test.

TABLE IV-Reported triggers of symptoms among 9-11 year old children with asthma and symptoms of rhinitis in Leipzig and Munich

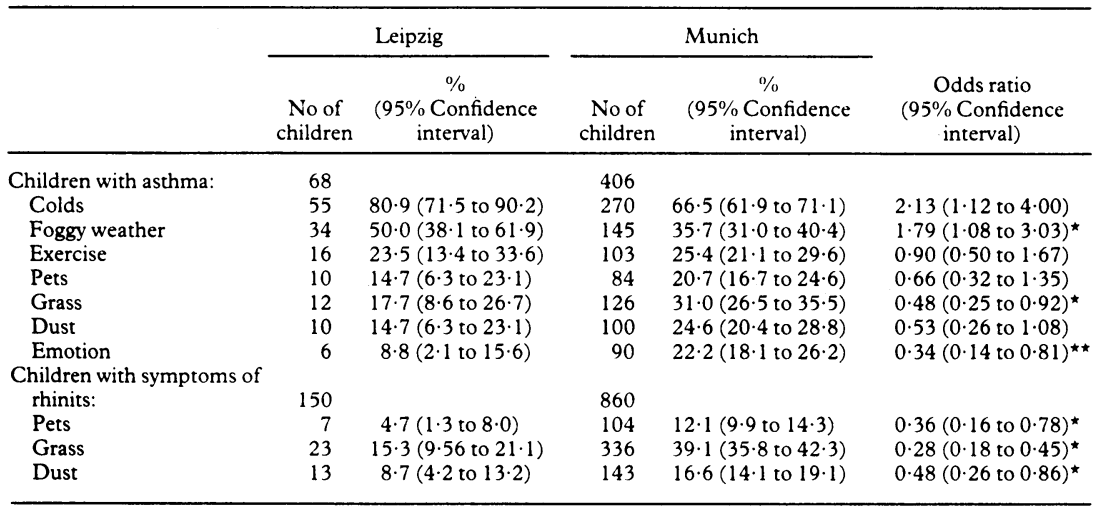

${ }^{\star} p<0.05,{ }^{\star \star} p<0.01$ by the two tailed exact Fisher test.

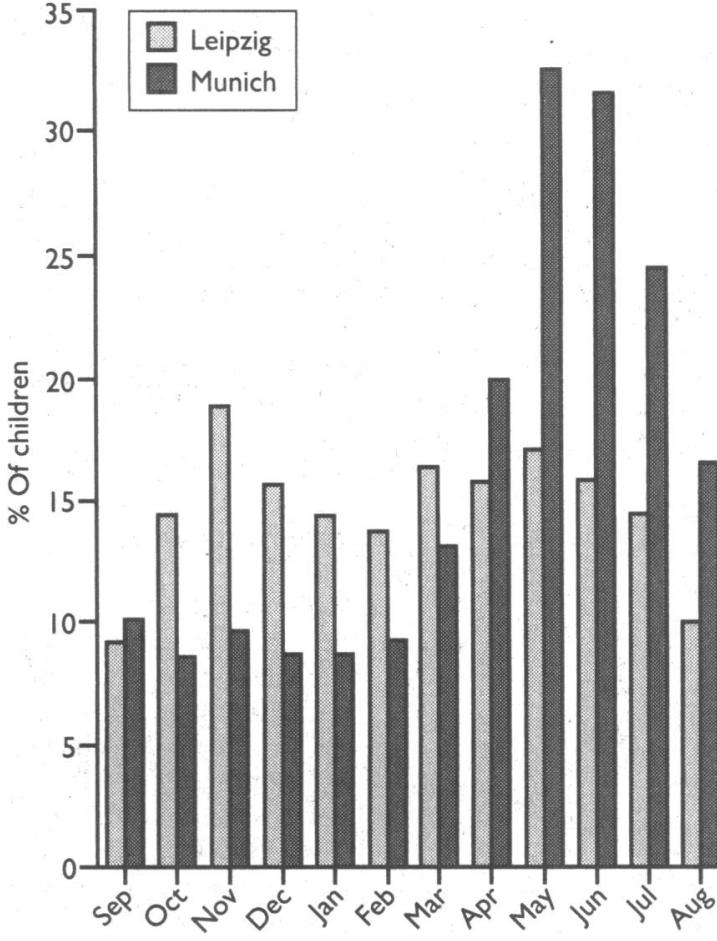

FIG 2-Proportion of children with rhinitis whose parents reported that symptoms occurred during specific months in Leipzig $(n=154)$ and Munich $(n=872)$

by parents from Leipzig than from Munich (table IV) Parents were also asked to indicate whether symptoms occurred during specific months. In Munich symptoms of rhinitis showed a strong peak during the summer months when pollen counts are high whereas in Leipzig the reported frequency of these symptoms increased only slightly during the summer and also increased during the winter months (fig 2). Atopic dermatitis diagnosed by a doctor and typical symptoms of atopic dermatitis were reported with similar frequency in the two study areas.

Of the eligible children for whom the questionnaire was returned, $889(95 \cdot 1 \%)$ from Leipzig and 4478 $(89 \%)$ from Munich participated in the lung function tests. The participating children in Leipzig and Munich were similar with regard to age, sex, height, and body weight. Baseline measures in Leipzig and Munich were $93 \cdot 1 \% v 98.3 \%$ of predicted for forced vital capacity and $96.0 \% \vee 97.5 \%$ of predicted for forced expiratory volume in one second. A significan drop in forced expiratory volume (more than $9 \%$ ) was measured in $6.4 \%$ (57) of the children in Leipzig and in $7 \cdot 7 \%$ (345) of the children in Munich (prevalence odds ratio $=0.81 ; 95 \%$ confidence interval 0.61 to 1.07 ).

\section{Discussion}

Our results indicate no large differences in the lifetime prevalence of asthma, wheezing, and bronchial hyperreactivity among children living in Leipzig and Munich. The prevalence of bronchitis and cough after exercise as well as during foggy or cold weather was higher in Leipzig than in Munich Allergic triggers of asthma and allergic rhinitis were less common in Leipzig than in Munich.

\section{METHODOLOGICAL PROBLEMS}

There may be some methodological limitations. The survey in Leipzig was conducted one year after the Munich study and in only a cluster sample of children. It is unlikely, however, that these differences had a major influence on the study results. Questions concerning the lifetime prevalence are obviously subject to recall bias, which could have operated differently in 
the two populations. Until recently people in Leipzig and Munich have lived in a different social and political environment which could have influenced their attitude towards physical complaints as well as their responses to the questionnaire.

Differences in the observed prevalence of doctor diagnosed asthma and bronchitis could be a reflection of different medical practice and diagnostic labelling in the formerly separated states. ${ }^{2 n}$ It is possible that some of the children with bronchitis in Leipzig would have had asthma diagnosed if they were in Munich. Parents of children with bronchitis, however, reported wheezing, attacks of shortness of breath, and nocturnal cough with similar frequency in both cities. Cough after exercise or during foggy or cold weather was reported more often by parents of children with bronchitis in Leipzig. The results of the cold air challenge provide further evidence for a similar prevalence of asthma in Leipzig and Munich. It is unlikely that the increased reporting in Leipzig is strictly a diagnostic bias, even though different diagnostic labeiling in the two cities cannot be fully excluded.

The prevalence of medically diagnosed hay fever, the most common form of allergic rhinitis, was much lower in Leipzig than in Munich. Differences in diagnostic labelling between the two cities could have influenced our findings. Nevertheless, not only were typical symptoms of rhinitis less common in Leipzig than in Munich, but parents in Munich also indicated allergic triggers and the typical seasonal pattern of rhinitis symptoms more often than those in Leipzig.

\section{AIR POLLLTION}

High levels of sulphur dioxide and particulate matter in the air have long been associated with respiratory illness in children and adults. ${ }^{27} 2 x$ A study of schoolchildren in Sheffield found increased rates of respiratory illness among children living in areas with high pollution from sulphur dioxide $\left(275 \mu \mathrm{g} / \mathrm{m}^{3}\right)$ and particulate matter $\left(301 \mu \mathrm{g} / \mathrm{m}^{3}\right) .^{20}$ A follow up study of these children four years later, after the introduction of a clean air programme, found big reductions in air concentrations of particulate matters and a fall in respiratory disease among the schoolchildren; concentrations of sulphur dioxide had decreased only slightly during this time. ${ }^{1 *}$ The individual contribution of both compounds of air pollution has since been debated. ${ }^{30} 31$

An increased prevalence of cough has been observed among children intermittently exposed to high concentrations of sulphur dioxide $\left(>2500 \mu \mathrm{g} / \mathrm{m}^{3}\right)$ at moderate levels of particulate sulphates." Experimental studies suggest that sulphur dioxide can increase airway resistance in subjects with pre-existing asthma but not in healthy subjects. ${ }^{22: 34}$ The American six cities study reported a positive correlation between the prevalence of bronchitis and chronic cough and exposure to particulate matter." 31 The odds of bronchitis and chronic cough increased by 2.3 and 3.4 respectively over the range of the observed concentrations $(34 \cdot 1$ $\left.80.0 \mu \mathrm{g} / \mathrm{m}^{3}\right)$ of total suspended particulates and the increase was statistically significant for the concentrations of particulate matter less than $15 \mu \mathrm{m}$ diameter. ${ }^{31}$ However, no association between exposure to particulate matter, nitrogen dioxide, or sulphur dioxide and the prevalence of persistent wheeze or asthma was

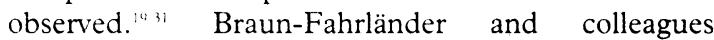
reported a correlation of levels of total suspended particulates with the incidence and duration of episodes of respiratory symptom among preschool children, ${ }^{2 *}$ while others observed an association of levels of particulate matter less than $10 \mu \mathrm{m}$ with hospital admission rates from respiratory illness. ${ }^{35}$

Our findings of an increased prevalence of bronchitis and frequent cough in Leipzig, which has higher levels of sulphur dioxide and particulate matter than Munich, confirm earlier reports of this association, ${ }^{14-2020-31}$ although the relative effects of both pollutants cannot be determined. In turn, the similar prevalence of asthma and bronchial hyperresponsiveness to cold air inhalation in both cities provides additional evidence $^{102930}$ that long term exposure to sulphur dioxide and particulate matter, even at the observed high levels, does not primarily affect bronchial hyperresponsiveness and asthma.

POPLLATION DIFFERENCES

Children in Munich are exposed to higher concentrations of nitrogen dioxide than those in Leipzig, which probably reflects the higher concentrations of automobile exhausts caused by heavy traffic in Munich. Diesel exhausts have been reported to have an adjuvant effect on allergic sensitisation in animal model ${ }^{36}$ and another study from Japan suggests that pollution from automobile exhaust in areas with high pollen counts may increase the incidence of hay fever in humans. ${ }^{16}$ Exposure to nitrogen dioxide and auto-mobile exhaust might be partly responsible for the higher prevalence of allergic rhinitis in Munich.

Not only air pollution but living conditions in the two cities have been very different over the past 45 years. Relevant differences between living conditions in Leipzig and Munich might include nutrition, parental smoking habits, housing conditions, and respiratory infections early in life. Our study based on only two centres does not allow us to attribute disease differentials to specific causes. We aimed at giving a descriptive comparison of the prevalence of asthma and allergic disorders among children living in western and eastern Germany. Further studies are currently underway to address aetiological questions in more detail. The apparently lower prevalence of allergic disorders in Leipzig was particularly interesting. These findings could point toward aetiological factors for allergic disease that are associated with the lifestyle and living conditions in Western industrialised countries.

We thank Professor Ross Anderson and Drs David Strachan and Dennis Nowak for useful comments.

1 Varonier HS, de Haller J, Schopfer C. Prévalence de l'allergie chez les enfants et les adolescents. Helv Paediatr Acta 1984;39:129-36.

2 Burr ML. Butland BK, King S, Vaughan-Williams E. Changes in asthma prevalence: two surveys 15 years apart. Arch Dis Child 1989;64:1452-6.

3 Burney PJ, Chinn S, Rona RJ. Has the prevalence of asthma increased in children? Evidence from the national study of health and growth 1973-86. BM7 1990:300:1306-10

4 Robertson CF, Heycock E, Bishop J, Nolan T, Olinsky A, Phelan PD. Prevalence of asthma in Melbourne schoolchildren: changes over 26 years. BM7 1991;302:1116-8.

5 Shaw RA, Crane J, O'Donnell TV, Portous LE, Coleman ED. Increasing asthma prevalence in a rural New Zealand adolescent population: 19751989. Arch Dis Child 1990;65:1319-23.

6 Mitchell EA, Jackson RT. Recent trends in asthma mortality, morbidity, and management in New Zealand. 7 Asthma 1989;26:349-54.

Friday GA, Fireman P. Morbidity and mortality of asthma. Pediatr Clin North Am 1988:35:1149-62.

8 Anderson HR. Increase in hospital admissions for childhood asthma: trends in referral, severity, and readmissions from 1970 to 1985 in a health region of the United Kingdom Thorax 1989;44:614

9 Mitchell EA, Dawison P. Why are hospital admissions of children with acute asthma increasing? Eur Respir 7 1989;2:470-2.

10 Fleming DM, Crombie DL Prevalence of asthma and hay fever in England and Wales, BM7 1987;294:279-83.

11 Wüthrich B, Schnevder UW, Henauer SA, Heller A. Häufigkeit der Pollinosis in der Schweiz. Schuceiz Med Wochenschr 1986;116:909-17.

12 Taylor B, Wadsworth J, Wadsworth M, Peckham C. Changes in the reported prevalence of childhood eczema since the 1939-45 war. Lancet 1984; $1255-7$.

13 Sporik R, Holgate ST, Platts-Mills TAE, Cogswell JJ. Exposure to house-dust mite allergen (Der p I) and the development of asthma in childhood. A prospective study. N Engl F.Med 1990;323:502-7.

14 Young S, Le Souef PN, Geelhoed GC, Stick SM, Turner KJ, Landau LI. The influence of a family history of asthma and parental smoking on airway responsiveness in early infancy. $N$ Engl 7 Med 1991:324:1168-73.

15 Strachan DP. Hav fever, hygiene, and household size, $B M 7$ 1989:299: $1259-60$.

16 Ishizaki T, Koizumi K, Ikemori R, Ishiyama Y, Kushibiki E. Studies of prevalence of Japanese cedar pollinosis among the residents in a densely prevalence of Japanese cedar pollinosis among the residents in a densely
cultivated area. Ann Allerg. 1987;58:265-70. 17 Andrae S, Axelson A, Björksten B, Fredriksson M, Kjellmann NIM 
Symptoms of bronchial hyperreactivity and asthma in relation to environmental factors. Arch Dis Child 1988;63:473-8.

18 Lunn JE, Knowelden J, Roe JW. Patterns of respiratory illness in Sheffield junior schoolchildren-a follow up study. Br f Prev Soc Med 1970;24:223-8. 9 Ware JH, Ferris BG Jr, Dockery DW, Spengler JD, Stram DO, Speizer FE. Effects of ambient sulfur oxides and suspended particles on respiratory health of pre-adolescent children. Am Rev Respir Dis 1986;133:834-42.

20 Braun-Fahrländer C, Ackermann-Liebrich U, Schwartz J, Rutishauser M, Gnehm HP, Wonner HU. Air pollution and respiratory symptoms in preschool children. Am Rev Respir Dis 1992;148:42-7.

21 Molfino NA, Wright SC, Katz I, Tarlo S, Silverman F, McClean PA, et al. Effect of low concentrations of ozone on inhaled allergen responses in asthmatic subjects. Lancet 1991;338:199-203.

22 Ferris BG. Epidemiology standardization project. Am Rev Respir Dis 1978;118 (suppl):7-53.

23 Nicolai T, Mutius E von, Reitmeir P, W jst M. Reactivity to cold air hyperventilation in normal and asthmatic children in a survey of 5697 school hyperventilation in normal and asthmatic children in a survey

24 Fleiss JL. Statistical methods for rates and proportions. New York: John Wiley, 1980.

25 SAS. Statistical analysis system. Version 6.06. Cary, North Carolina: SAS, 1990.

26 Steinbrück P, Herrmann H, Landmann H. Empfehlungen der Problemkeinbrück $\mathrm{P}$, Herrmann $\mathrm{H}$, Landmann $\mathrm{H}$. Empfehlungen der Problem-
kommion für Lungenkrankheiten und Tuberkulose zur Definition von chronischer Bronchitis, Asthma bronchiale und Lungenemphysem. Monatsschrift für Lungenkrankheiten und Tuberkulose Bekämpfung 1969;12: 289-98.

27 Logan WPD. Mortality in London fog incident. Lancet 1953;i:336-8.

\section{Medical management of missed abortion and anembryonic pregnancy}

\author{
H El-Refaey, K Hinshaw, R Henshaw, \\ N Smith, A Templeton
}

Miscarriage is the most common complication of pregnancy and probably accounts for around 50000 inpatient admissions in the United Kingdom each year. Generally, its management has changed little with time. Recently developments in non-surgical treatment, refined in induced abortion, offer an opportunity to improve management and to remove the need for surgery and anaesthesia. We report our initial experience of the use of mifepristone (an antiprogesterone) and misoprostol (a synthetic analogue of prostaglandin $\mathrm{E}_{1}$ ) in the management of missed abortion and anembryonic pregnancy (gestation sac present but no developing embryo).

\section{Patients, methods, and results}

Sixty women with a diagnosis of missed abortion or anembryonic pregnancy equivalent to 13 weeks' gestation or less were recruited after counselling. Twenty five of the women had been referred for ultrasound scanning because of bleeding in early pregnancy, while in the remainder the diagnosis had been made on routine scanning when they booked. Patients in whom an incomplete abortion was diagnosed were not included.

Each patient was given a single oral dose of mifepristone $600 \mathrm{mg}$ and was admitted to the gynaecological ward as an outpatient $36-48$ hours later, when misoprostol $600 \mu \mathrm{g}$ was given orally in a divided dose (400 $\mu \mathrm{g}$ and, two hours later, $200 \mu \mathrm{g}$ ). The patient's pulse, blood pressure, and temperature were recorded hourly, as were any side effects and requests for analgesia. If the products of conception were not expelled and verified within four hours vaginal ultrasonography was performed. If the gestation sac was not seen and bleeding had occurred the procedure was considered to have been successful, but if not the patient was offered evacuation of the uterus under general anaesthesia. All patients were reviewed 10-14 days later.

The median age of the 60 women was 27 (range 15-44), and the median duration of amenorrhoea was $71(42-110)$ days. Twenty nine patients were diagnosed as having anembryonic pregnancies and the remaining 31 as having had a missed abortion. One of the patients thought to have an anembryonic pregnancy was
28 Gore AT, Shaddick CW. Atmospheric pollution and mortality in the county of London. Br f Prev Soc Med 1968;12:104-13.

29 Lunn JE, Knowelden J, Handyside AJ. Patterns of respiratory illness in Sheffield infant school children. Br J Prev Soc Med 1967;21:7-16.

30 Dodge R, Solomon P, Moyers J, Hayes C. A longitudinal study of children exposed to sulfur oxides. Am F Epidemiol 1985;121:720-36.

31 Dockery DW, Speizer FE, Stram DO, Ware JH, Spengler JD, Ferris BG. Effects of inhalable particles on respiratory health of children. $\mathrm{Am}$ Rev Respir Dis 1989;139:587-94.

32 Koenig JQ, Morgan MS, Horike M, Pierson WE. The effects of sulfur dioxides on nasal and lung function in adolescents with extrinsic asthma.W f Allergy Clin Immunol 1985;76:813-8.

33 Sheppard D, Wong WS, Uehara JA, Nadel JA, Boushey HA. Lower threshold $C$ and greater bronchomotor responsiveness of asthmatic subjects to sulphur $\Rightarrow$ dioxide. Am Rev Respir Dis 1980;122:873.

34 Jorres $\mathrm{R}$, Magnussen $\mathrm{H}$. Airways response of asthmatics after a 30 min exposure, at resting ventilation, to $0.25 \mathrm{ppm} \mathrm{NO}$ or $0.5 \mathrm{ppm} \mathrm{SO} 2$. Eur Respir f 1990;3:132-7.

35 Pope CA. Respiratory disease associated with community air pollution and $\overline{\bar{C}}$ steel mill, Utah Valley. Am $\mathcal{F}$ Public Health 1989;79:623-8.

36 Takafuji S, Suzuki S, Koizumi K, Tadokoro K, Miyamoto T, Ikemori R, et al. Diesel-exhaust particulates inoculated by the intranasal route have an adjuvant activity for IgE production in mice. I Allergy Clin Immunoles 1987;79:639-45.

(Accepted 6 October 1992)

eventually found to have an ectopic pregnancy whenc she failed to abort. She has been excluded from furthero consideration.

Eight patients aborted with mifepristone alone. Of the 51 remaining patients, 43 aborted after taking misoprostol $600 \mu \mathrm{g}$ and five more aborted afterc receiving a second divided dose of $600 \mu \mathrm{g}$ misoprostol. In three patients the treatment failed, and they under- $\mathrm{C}$ went evacuation of the uterus under general anaes- $c$ thesia. Exploratory curettage was performed in two other patients at 14 and 22 days after treatment with misoprostol, but no products of conception were obtained.

The median time from administration of misoprostol $\vec{c}$ to abortion was 4 (range 1-11) hours. The mediane duration of bleeding after abortion was 10 (2-22) days. There were no cases of infection, and no patiento required antibiotic treatment. Side effects from misoprostol treatment (nausea, vomiting, and diarrhoea) were few: antiemetic drugs were given to five patients, and diarrhoea was reported by seven. Thirty nine women did not ask for any pain relief, 13 requested oralō analgesia, and seven required parenteral analgesia.

\section{Comment}

The medical management of induced abortion is now established practice, and several centres haveo developed considerable skill in using mifepristone with a variety of prostaglandin analogues..$^{1-4}$ We have showno the clinical feasibility of managing missed abortion and anembryonic pregnancy medically without resort too surgery or anaesthesia. Patients' perceptions at this early stage of development of the method are positive but need to be assessed more thoroughly, particularlyo in relation to the alternatives. The implications in terms of resources are considerable since if this methodo became standard practice a major part of emergencyew work in gynaecology would be removed from the operating room and could be managed at times more? convenient to patients and staff.

1 UK Multicentre Trial. The efficacy and tolerance of mifepristone and prostaglandin in first trimester termination of pregnancy. $\mathrm{Br} \quad \mathrm{f}$ Obste Gynaecol 1990;97:480-6.

2 World Health Organisation Task Force on Postovulatory Methods for Fertility Regulation. Termination of early human pregnancy with RU480 (mifepristone) and the prostaglandin analogue sulprostone: a multicentre randomized comparison between two treatment regimens. Hum Reprose randomized

3 World Health Organisation. Pregnancy termination with mifepristone anc gemeprost: a multicentre comparison between repeated doses and a single gemeprost: a multicentre comparison between

4 Norman JE, Thong KJ, Baird DT. Uterine contractility and induction of abortion in early pregnancy by misoprostol and mifepristone. Lance? 1991;338:1233-6.

(Accepted 23 October 1990) 